\title{
Valuing Dynamic Capabilities-Based Synergies with Real Options
}

\author{
Andrejs Čirjevskis (B)
}

check for updates

Citation: Čirjevskis, Andrejs. 2021. Valuing Dynamic Capabilities-Based Synergies with Real Options. Journal of Risk and Financial Management 14: 69. https://doi.org/10.3390/jrfm14020069

Academic Editor: Renata Korsakienè

Received: 3 January 2021

Accepted: 3 February 2021

Published: 7 February 202

Publisher's Note: MDPI stays neutral with regard to jurisdictional claims in published maps and institutional affiliations.

Copyright: (c) 2021 by the author Licensee MDPI, Basel, Switzerland. This article is an open access article distributed under the terms and conditions of the Creative Commons Attribution (CC BY) license (https:// creativecommons.org/licenses/by/ $4.0 /)$
Department of Business, RISEBA University of Applied Sciences in Business, Arts, and Technology, Meza Street 3 LV-1048 Riga, Latvia; andrejs.cirjevskis@riseba.lv

Abstract: Acquisition-based dynamic capabilities have become well established as a new imperative for organizing mergers and acquisitions (M\&A) processes. However, understanding the full benefits and possible limits of real options applications to measure a dynamic capability-based synergy in M\&A deals remains a challenge. This paper draws on real options theory to explore some of these benefits and limits to value a synergy in two highly strategic M\&A deals. More specifically, the author develops the proposition that justifies the role of dynamic capabilities as antecedents of the success of M\&A deals in the information and communications technology industry and demonstrates real options application to measure M\&A synergies.

Keywords: real options; synergy; acquisition; dynamic capabilities; business model; the ICT industry

\section{Introduction: Purpose, Motivation, and Originality \\ 1.1. Research Objective and Approach}

The objective of this article is to explore the antecedents of the dynamic capabilitiesbased synergies in mergers and acquisitions (M\&A) deals and to demonstrate an application of real options to measure those synergies. The paper argues that the intersection of the framework of dynamic capabilities and real options theory can shed light on the antecedents of successes (synergies) of M\&A deals in the information and communications technology (ICT) industry.

The paper develops a proposition as follows. Dynamic capabilities-based synergies in M\&A deals provided by the degree of their similarities, complementarity, and transferability can be valued by real options application using the Black-Scholes Option Pricing Model (BSOPM) and Binominal Option Pricing Model (BOPM).

\subsection{Research Motivation and Originality}

The motivation for this research is as follows. Even though the dynamic capabilities framework and its empirical applications (Teece 2007, 2011; Capron and Anand 2007) make dynamic capabilities more visible and tangible, the real options application is making dynamic capabilities measurable, at least in such collaborative types of strategies as M\&A deals. The author uses the real options valuation approach to measuring synergies of recent M\&A deals in ICT industries, namely, LinkedIn acquisition by (Microsoft 2016), and Amazon's acquisition of Whole Foods in 2017.

The author selected the two mentioned cases due to the following reasons. First, the ICT industry is a global dynamic and highly competitive industry, and to sustain competitive dynamic capabilities. Second, the acquisitions of LinkedIn and Whole Foods by Microsoft and Amazon were incredibly interesting, highly strategic, and not standard (Clarence-Smith 2020). So, what do two global ICT industry leaders, namely, Microsoft and Amazon hope to gain with those mergers? This paper demonstrates originality by analyzing antecedents of acquisitions giants through the lenses of dynamic capabilities framework, building blocks of business models, and consequences of acquisitions (synergies) through the lenses of real options theory. 


\subsection{Research Topicality, Contributions, and Structure}

Scholars have opportunities to deepen and broaden our understanding of the dimensions of dynamic capabilities, including their micro-foundations (Wilden et al. 2016; Schilke et al. 2018). This paper researches the synergies' phenomenon in the context of M\&A deals of the ICT industry. Thereby, the paper contributes to the current discussion on triggers of dynamic capabilities of M\&A deals in ICT industries, on the processes of the reinvention of an acquirer's business model, and dynamic capabilities-based synergies as an organizational outcome of those processes. In this vein, two exploratory case studies justify the proposition and unpack micro-foundations of acquisition-based dynamic capabilities. Namely, the paper illustrates what triggers the dynamic capabilities of an acquirer, why and how those capabilities underpin a reinvention of the acquirer's business model, and how to measure a dynamic capabilities-based synergy of collaborative strategies with real options theory.

This paper is organized as follows. First, the dynamic capabilities as antecedents of successful M\&A deals are discussed in terms of abilities to integrate two business models of an acquirer's and a target's companies in search of synergies. The section is devoted, respectively, to developing the proposition that can be justified empirically by analysis of the recent two explorative case studies. The following sections demonstrate the use of real options to measure dynamic capabilities-based synergies of the two above-mentioned acquisitions. The paper ends with a discussion on managerial and theoretical contributions. In conclusion, the paper highlights the research limitations and future works.

\section{Theoretical Background}

Dynamic capabilities are the renewing and regenerative capabilities that enable firms to change their operating processes incrementally and radically. Real options valuation provides an appropriate platform for firms to measure managerial flexibilities and, thereby, dynamic capabilities.

\subsection{Exploring Dynamic Capabilities and Business Models in Merger and Acquisition $(M \mathcal{E} A)$ Deals}

Teece (2014, p. 328) argues that the "dynamic capabilities framework was created ... to help scholars and practitioners understand the foundations of firm-level competitive advantage." A dynamic capabilities framework emphasizes how a successful firm can "integrate, build, and reconfigure internal and external competencies to address rapidly changing environments" (Teece et al. 1997, p. 516). There is very little research on acquisition-based dynamic capabilities. Teece argues that it might be "because assets are bundled together often tightly linked inside incumbent firms, it may be difficult to obtain assets in the desired configurations through asset purchase or sale in mergers and acquisitions" (Teece 2007). What is more, there is no consensus on how to measure synergies in merger and acquisition deals created by dynamic capabilities.

Similarity and complementarity of dynamic capabilities affect post-M\&A deals' outcomes. "Studies give clear empirical evidence that complementarities are a significant factor for M\&A success" (Bauer and Matzler 2014, p. 272). Thanks to the interaction of complementary characteristics, value creation occurs not only through cost savings but also through the growth of turnover and market share due to dynamic opportunities (Kleinbaum and Stuart 2014). Moreover, Signoria and Vismara (2018) measure business similarity as a proxy for Mand A synergies. In this vein, an application of real options to measure market value added by the similarities and complementarity of dynamic capabilities is an appropriate approach. In the recent publications, scholars argue and demonstrate (Čirjevskis 2017, 2019a, 2019b) that a dynamic capabilities framework of Teece $(2007,2011)$ is a useful tool of business analyses for M\&A deals to identify similarities and complementarity of an acquirer's and a target's dynamic capabilities.

The business model frameworks were developed as instruments for visualization of customer value proposition, cost structure, and profit formula of early-stage endeavor. 
What is more, business models "have considerable significance but are poorly understood-frequently mentioned but rarely analyzed" (Teece 2010, p.192). According to Teece (2018), the most important components of business models are to unmet customer needs, specifying the technology that will address them, and capturing value from the activities. Moreover, Teece argued that "business models, dynamic capabilities, and strategy are interdependent. The strength of a firm's dynamic capabilities helps shape its proficiency at business model design" (Teece 2018, p. 40).

Management's ability to develop and refine business models is a core micro foundation of dynamic capabilities (Teece 2007). Scholars should dig deeper to explore the connection of acquisition-based dynamic capabilities and their micro-foundations of the reinvention of a business model of an acquirer and synergies in M\&A deals. Recently Corbo et al. (2020) developed the continuous validation framework (CVF) as a mechanism in business model design and presented a sequence of steps of reinvention in relation to the building blocks of a business model that might be followed to sustain a new competitive advantage.

\subsection{Exploring the Link of Real Options Theory with Dynamic Capabilities Framework in MEA Deals}

By definition, a financial option gives its holder the right, but not the obligation, to buy or sell the underlying asset at a specified price (i.e., the exercise price) on or before a given date (i.e., the expiration date). The holder of a call option on a financial asset who finds the option to be in the money can simply exercise the option and cash in on the difference between the market price and exercise price specified in the option contract (Ragozzino et al. 2016).

Options considered in corporate finance and strategic management labeled as "real" represent claims on real (physical) assets and not financial ones (Damodaran 2002, p. 16; Li et al. 2007). Thus, a real option is understood as the right and not the obligation to pursue a particular investment in a pre-determined time frame (Luehrman 1998; Adner and Levinthal 2004). The idea behind the current research is to view an acquisition as a growth option on potential benefits since acquisitions can open opportunities that would not have been available otherwise (Damodaran 2005).

Now, we link the dynamic capabilities framework with a real options valuation model. From a real options and dynamic capabilities perspective, where the firm is going in the future depends on the opportunities that lie ahead and management's dynamic strategic plans (Smit and Trigeorgis 2004). Teece (2014) defines that dynamic capabilities can usefully be broken down into three primary clusters: (1) identification, development, co-development, and assessment of technological opportunities concerning customer needs (sensing); (2) mobilization of resources to address needs and opportunities, and to capture value from doing so (seizing); (3) continued renewal (transforming).

In turn, Damodaran argued, " . . that the real options argument is heavily dependent upon two concepts-the learning that occurs by being in a new market and the more informed decisions that flow from the learning" (Damodaran 2005, p. 20). What is more, scholars argue that learning mechanisms guide the evolution of dynamic capabilities (Eisenhardt and Martin 2000; Winter 2003). Easterby-Smith and Prieto (2008) consider a process of learning as a possible central element in the creation and renewal of dynamic capabilities. Thus, since dynamic capabilities arise from learning and they constitute the firm's systematic methods for modifying operating routines (Zollo and Winter 2002), we can propose that the real options argument is tightly dependent upon the dynamic capabilities' framework.

In this vein, Nishihara (2012) studied dynamic management of multiple real options and highlighted the advantage of dynamic management over static management. Having compared static and dynamic management of multiple real options, Nishihara (2012) has found that a firm under static management determines the type of exercise of real options ex-ante; on the other hand, a firm under dynamic management decides the time of exercise and enjoys the synergy gains even for weakly correlated projects. What is more, Nishihara 
(2018) argued that the real option can capture market uncertainty, which dynamically changes due to specific and macroeconomic shocks on the demand market.

Thereby, the real option can measure dynamic management (Nishihara 2012), which is provided by the dynamic capabilities of the acquirer's and target's companies, namely, by co-development of technological opportunities in the relationship to changing customer needs (sensing), by capturing value from doing so, (seizing), and continued renewal (transforming).

Smith and Triantis (1995) argue that acquisition creates valuable growth options that discounted cash flow models do not capture. These growth options can be the result of more growth opportunities, a better competitive position for the combined firm, and add value (synergies) to the acquiring firm. The idea of the growth option is that acquisition of a target company is like purchasing a call option on the value of a subsequent target. By engaging in the acquisition, the acquirer earns the right but not the obligation to develop a subsequent target. These assumptions are identical to the growth option.

The value of the growth option at the time of the getting synergies is added to the value of an acquirer and a target without acquisition. Let us consider the first case study example of the Microsoft corporation buying LinkedIn in an emerging market of professional social networking with immense growth potential. The acquiring corporation Microsoft is buying is an option to expand in the emerging social network market rather than a set of expected cash flows.

\subsection{Valuing Dynamic Capabilities-Based Synergies with a Real Options Application}

"Synergies do not magically materialize. By definition, they are possibilities, not certainties" (Ficery et al. 2007, p. 35). There is no single way to identify, validate, and value the potential of dynamic capabilities-based synergy. " ... Discounted cash flow models are too limiting when it comes to valuing synergy. The synergy benefits in most acquisitions ... can be better understood using an options framework ... " (Damodaran 2005, p. 19). Even, " ... the NPV does not properly capture the dynamics and active management of investment under uncertainty, except indirectly (and inadequately) through the adjustment of discount factors" (Smit and Trigeorgis 2004, p. 103).

An evaluation of synergy in a dynamic environment is often more complex than standard discounted cash flow (DCF) analysis may suggest, which implicitly assumes a static view of investment decisions and projected cash flow scenarios (Smit and Trigeorgis 2004). "A real-options framework adds a dynamic perspective to the traditional valuation approach by incorporating the value of flexibility and growth opportunities in an uncertain environment". (Smit and Trigeorgis 2004, p. 94).

Dunis and Klein (2005) argue that synergies can be assessed as a real option value, employing input variables for the European and/or American call options with Black-Scholes Option Pricing Model and/or accordingly with the Binominal Option pricing model.

"The option on potential merger benefits to the shareholders is a European call option on the market value of the merged company with the expected future stand-alone market value defined as the exercise price" (Dunis and Klein 2005, p. 7). "The share price equivalent of the option is the cumulated market value of target and acquirer before the announcement of the deal terms" (Dunis and Klein 2005, p. 7). Thus, the share price (So) is proxied by the sum of capitalization of merging companies before the deal's announcement.

"The exercise price is the hypothetical future market value without the merger ... The exercise price is the combined hypothetical future market value after one year" (Dunis and Klein 2005, p. 7). According to Dunis and Klein (2005), the exercise price (K) is proxied by the sum of the future market capitalization of the merging companies in one year if the merger is not be consummated. The future capitalization of two separate companies can be calculated by employing a discounted free cash flow method. Cash flow is, in theory, the free cash flow, but in practice, it is proxied by earnings before interest, taxes, depreciation, and amortization (EBITDA). Therefore, the exercise price is the hypothetical future market 
value without the merger or theoretical market value calculated by using revenue and EBITDA multiples.

The volatility $(\sigma)$ of share price can be obtained from the V-Lab APARCH Volatility Analysis (NYU Stern) or by the calculation of the standard deviation of the acquirer stock price return that was started the week after the announcement (Dunis and Klein 2005).

As to the duration (T) of achieving synergy, Dunis and Klein assumed one year for the time to maturity (Dunis and Klein 2005, p. 7). However, other studies use different values in M\&A of listed companies, using 3 years for acquisitions (Vergos 2003) or using even larger periods, up to ten years (Damodaran 2002). For time to maturity, one year was assumed for the deals of Microsoft-LinkedIn and Amazon-Whole Foods. This was due to data availability and the assumption that efficient markets should have well-anticipated potential long-term merger gains within this period. The US dollars was chosen as the reference currency for those two acquisitions. The risk-free rate (Rf) is a long-term government bond yield of an acquirer's country (Dunis and Klein 2005).

The option premium gives the value of this option and should be equivalent to the takeover premium or even bigger. The acquisition is justified only when the perceived value to the buyer is greater than the exercise price (Kogut 1991). "This call option is in the money if the market value of the merged entity exceeds the expected future market value of the two separate companies." (Dunis and Klein 2005, p. 6). In this vein, the value of a real option is a synergy being added to the value of the combined firm, reflecting the time premium on the option. The option premiums as a competence-based synergies result can be calculated using an Excel spreadsheet. Therefore:

Proposition 1. Dynamic capabilities-based synergies provided by the degree of their similarities, complementarity, and transferability in MEA deals can be valued by real options application using the Black-Scholes Option Pricing Model (BSOPM) and Binominal Option Pricing Model (BOPM).

To test the internal and external validity of the proposed proposition, it was applied to two exploratory cases of dynamic capabilities-based M\&A deals in the ICT industry in the years 2016 and 2017.

\section{The First Explorative Case Study: Microsoft's Acquisition of LinkedIn in 2016}

On 11 June 2016, Microsoft Corporation announced a merger with LinkedIn under which the transaction valued at approximately USD $26.2 \mathrm{bn}$. What triggers the acquisitionbased dynamic capabilities of such a technologically advanced corporation such as Microsoft? What similarities and complementarity of dynamic capabilities of Microsoft and LinkedIn existed and what building blocks of the business model of LinkedIn could be transferred to Microsoft's business model?

Regarding the similarities of the dynamic capabilities, both companies were successful when they were developing new market niches, Microsoft with Office products and LinkedIn with its professional social network. Both companies were successful in sensing possible needs in non-developed markets, seizing popular products and services and keeping them on track over the years, maintaining leading positions and achieving satisfactory results. Companies used both in-house resources and acquisitions for transformation, developing new tools, and adopting products to various operational systems.

When it comes to its complementarities and triggers of acquisition-based dynamic capabilities, the first trigger is the fact that Microsoft was behind iOS and Google mobile ecosystems. Moreover, the Skype example shows that Microsoft was rather weak in sensing in already developed, rapidly growing markets, such as consumer internet. The dynamic capabilities of Microsoft showed poor results when the company tried to gain leadership positions in an already developed market. In contrast, LinkedIn successfully runs a social network on mobile devices with a high mobile presence (60\% of users).

The second trigger is the deal as a means for Microsoft to foray into the professional social networking space. LinkedIn had immense potential to grow as a professional social network with revenue generation similar to that of a software business. However, despite 
having a strong user base of 433 million in 2016, LinkedIn continued its struggle to grow the user base and had little scope for profit.

Thereby, LinkedIn's users offered opportunities for Microsoft to develop its cloud and customer relationship management initiatives (Sapersen and Gonzales 2017). As far as Microsoft was concerned, the main objective for the tech giant was to occupy a position at the center of peoples' business lives. That leads to the conclusion that the building blocks of the corporation's business model are compatible and transferable if Microsoft keeps LinkedIn autonomous in its development and provides it resources for the development.

In turn, it evidences the high probability to generate dynamic capabilities-based synergies in the acquisition of LinkedIn. The acquisition-based dynamic capabilities helped Microsoft to innovate a business model by obtaining managerial synergies as shown in Table 1.

Table 1. The micro-foundations of the reconstructs of the business model of Microsoft by acquisition-based dynamic capabilities.

\begin{tabular}{cc}
\hline Acquisition-Based Dynamic Capabilities of Microsoft & $\begin{array}{c}\text { Micro-Foundations (Processes) of the Reconstruct of the } \\
\text { Components of Microsoft Business Model }\end{array}$ \\
\hline $\begin{array}{c}\text { Identification, development, co-development, and assessment } \\
\text { of technological opportunities concerning customer needs } \\
\text { (sensing). }\end{array}$ & $\begin{array}{c}\text { Microsoft sensed opportunities to expand their market due to } \\
\text { the customer base of LinkedIn, accelerate the cloud and mobile } \\
\text { business, and improve customers' productivity and experience. }\end{array}$ \\
$\begin{array}{c}\text { Mobilization of resources to address needs and opportunities, } \\
\text { and to capture value from doing so (seizing). }\end{array}$ & $\begin{array}{c}\text { Microsoft captured value from combining their growing } \\
\text { business in cloud and business analytics with the existing } \\
\text { content of LinkedIn and providing intelligent insights for the } \\
\text { social business network. }\end{array}$ \\
$\begin{array}{c}\text { Continued renewal (transforming) customer relationships, new } \\
\text { channels, and new customer value proposition. }\end{array}$ & $\begin{array}{c}\text { The integration of LinkedIn's marketing solution products into } \\
\text { Microsoft products, such as Office365 and Dynamics, could } \\
\text { increase the number of users and create a deeper relationship } \\
\text { between users. The acquisition helps Microsoft to establish a } \\
\text { "net mobile presence". }\end{array}$ \\
\hline
\end{tabular}

Source: Developed by the author.

To measure dynamic capabilities-based synergies of the Microsoft acquisition, and to justify the proposition, the author used real options application employing BSOPM and BOPM. The first valuation model used to measure dynamic capabilities-based synergies in M\&A deal was based on the Black-Scholes option pricing model (Black and Scholes 1973), namely: $\mathrm{C}(\mathrm{S}, \mathrm{t})=\mathrm{S} 0 \times \mathrm{N}\left(\mathrm{d}_{1}\right)-\mathrm{K} \times \mathrm{e}^{-\mathrm{rT}} \times \mathrm{N}\left(\mathrm{d}_{2}\right)$, where $\mathrm{N}\left(\mathrm{d}_{1}\right), \mathrm{N}\left(\mathrm{d}_{2}\right)$ are the cumulative distribution functions of the standard normal distribution; $\mathrm{C}(\mathrm{S}, \mathrm{t})$ is call option price at time $\mathrm{t}$; $\mathrm{S} 0$ is the price of the underlying asset at time $0 ; \mathrm{K}$ is the exercise price at time $\mathrm{t}$; $\mathrm{T}$ is time in years; $\mathrm{r}$ is a risk-free rate; $\mathrm{e}$ is a mathematical constant approximately equal to 2.71828 , the base of the natural logarithm; $\sigma$ is expected volatility of an underlying asset's value.

On 13 June 2016, the capitalization of Microsoft was USD $394.1 \mathrm{bn}$; the capitalization of LinkedIn was USD 25.7 bn (Pillars of Wall Street 2017). The first valuation model used to measure dynamic capabilities-based synergies in M\&A deals was based on the Black-Scholes option pricing model (Black and Scholes 1973) as shown in Tables 2 and 3.

Dynamic capabilities-based synergies of Microsoft's acquisition of LinkedIn are USD 92.8 bn by BSOPM valuation. The valuation of the acquisition's synergies by the Binominal Option Pricing Model (BOPM) is USD 91.3 bn and given in Tables 4-6. 
Table 2. Option's variables to value dynamic capabilities-based synergies of Microsoft and LinkedIn's M\&A deal with BSOPM.

\begin{tabular}{cr}
\hline Option Variables & Data \\
\hline $\mathrm{S}(\mathrm{t})$ & On 13 June 2016, Microsoft's market capitalization was USD 394.1 bn and LinkedIn's capitalization was \\
USD 25.7 bn. Therefore, S(t) was USD 419.8 bn (Pillars of Wall Street 2020).
\end{tabular}

Source: Developed by the author.

Table 3. Valuation of dynamic capabilities-based synergies with the Black-Scholes option pricing model: Microsoft's acquisition of LinkedIn, in USD bn.

\section{Real Options Valuation with the Black-Scholes Option Pricing Model}

Cumulative capitalization of Microsoft and LinkedIn before the announcement in June 2016 (So)

The cumulative theoretical market value of two separated entities without a merger after one year in 2017 (K)

The risk-free rate of return (Rf) on 13 June 2016

Time to expiration in years $(\mathrm{T})$

The volatility of future share price of Microsoft $(\sigma)$ on 13-20 June of 2016 one week after the announcement of a deal

d1

d2

Value of the call option $(C)=$ Synergies

419.80

362.96

$1.62 \%$

1

$36.40 \%$

Source: Developed by the author.

Table 4. Recombining binomial lattice parameters (Microsoft's acquisition of LinkedIn).

\begin{tabular}{cc}
\hline \multicolumn{2}{c}{ Parameters of the Binominal Option Pricing Model } \\
\hline time increment (years) & $\delta \mathrm{t}=\frac{\mathrm{t}}{\mathrm{N}}=0.20$ \\
\hline up factor $(\mathrm{u})$ & $\mathrm{u}=\mathrm{e}^{\sigma \sqrt{ }{ }^{\Delta \mathrm{T}}=\frac{1}{\mathrm{~d}}=1.177}$ \\
\hline down factor $(\mathrm{d})$ & $\frac{1}{\mathrm{u}}=0.850$ \\
\hline risk-neutral probability $(\mathrm{p})$ & $\mathrm{p}=\frac{\mathrm{e}^{\mathrm{r} \Delta \mathrm{T}}-\mathrm{d}}{\mathrm{u}-\mathrm{d}}=0.469$ \\
\hline
\end{tabular}

Source: Developed by the author.

Once the binominal tree of assets value is completed, the next step is to calculate the possible payoff synergies) and roll back the values using risk-neutral probabilities as given in Table 6.

Thus, the forecasted market capitalization of Microsoft Inc. in one year after the acquisition of LinkedIn is the cumulative capitalization of a target and an acquirer before the announcement-(So) USD 419.8 bn plus estimated synergies of USD $92 \mathrm{bn}$, which equals USD 511.8 bn. Microsoft capitalization on 19 June 2017 was USD 551.59 bn. Therefore, expected synergies were fully realized and the added market value even bigger than predicted. However, the connection of the theoretical value with actual value largely depends on the timing of the prices taken and is entirely difficult to justify precisely in this study. Meanwhile, having compared the calculated option value with the takeover premium paid, one should be concluded that this acquisition added market value to Microsoft corporation thanks to dynamic capabilities-based synergy. 
Table 5. BOPM lattice of the underline values of Microsoft after the acquisition of LinkedIn (in USD bn).

\begin{tabular}{|c|c|c|c|c|c|}
\hline 0 & 1 & 2 & 3 & 4 & 5 \\
\hline \multirow[b]{5}{*}{$\begin{array}{l}\text { Underline } \\
\text { value }\end{array}$} & & & & & USD 947.39 \\
\hline & & & & USD 805.06 & \\
\hline & & & USD 684.12 & & USD 684.12 \\
\hline & & USD 581.35 & & USD 581.35 & \\
\hline & USD 494.01 & & USD 494.01 & & USD 494.01 \\
\hline \multirow[t]{4}{*}{ USD 419.80} & & USD 419.80 & & USD 419.80 & \\
\hline & USD 356.73 & & USD 356.73 & & USD 356.73 \\
\hline & & USD 303.14 & & USD 303.14 & \\
\hline & & & USD 257.60 & & USD 257.60 \\
\hline
\end{tabular}

Source: Developed by the author.

Table 6. BOPM of real options lattice: a value of Microsoft synergies of the acquisition of LinkedIn (in USD bn).

\begin{tabular}{|c|c|c|c|c|c|}
\hline 0 & 1 & 2 & 3 & 4 & 5 \\
\hline \multirow{6}{*}{$\begin{array}{c}\text { Value of call } \\
\text { option (synergies) } \\
\text { USD } 91.3\end{array}$} & & & \multirow{4}{*}{\multicolumn{2}{|c|}{$\begin{array}{l}\text { USD } 443.28 \\
\text { USD } 219.56\end{array}$}} & \multirow{2}{*}{ USD 584.43} \\
\hline & & & & & \\
\hline & & & & & \multirow{2}{*}{ USD 321.16} \\
\hline & & USD 222.82 & & & \\
\hline & USD 145.70 & & USD 135.14 & & \\
\hline & & USD 78.39 & & USD 61.31 & \multirow{3}{*}{ USD 0.00} \\
\hline & USD 43.77 & & USD 28.68 & & \\
\hline & & USD 13.42 & & USD 0.00 & \\
\hline & & & USD 0.00 & & USD 0.00 \\
\hline & & & & & USD 0.00 \\
\hline
\end{tabular}

Source: Developed by the author.

\section{Second Explorative Case Study: Amazon's Acquisition of Whole Foods}

On 16 June 2017 Amazon.com announced that it would purchase Whole Foods Market for a total of USD 13.7 billion. So, what do Amazon hope to gain with this acquisition? There are several similarities between the dynamic capabilities of Amazon and Whole Foods. Both companies are sensing market demands and seizing external opportunities in online and offline grocery businesses. However, their transforming capabilities need to be mutually complemented. There are several complementarities between the dynamic capabilities of Amazon and Whole Foods.

One of Amazon's weaknesses is the huge cost of losses due to food items becoming bad, a problem which the company had never faced with toys and books and had no great experience in the offline retail environment. In contrast, Whole Foods became an organic supermarket that distinguishes itself by offering "highest quality natural and organic products". The first trigger of acquisition-based dynamic capabilities is as follows. To grab more grocery market share, Amazon should learn to sell food offline (Kowitt 2018).

On the other hand, having a variety of niche products with a high price charge, the growth of Whole Foods had slowed because competitors began to offer organic foods at a lower price. From 2013 to 2016, Whole Foods lost nearly half its market value (Helmore 2017). That is why just a few days after the merger, Amazon dropped prices by as much as $43 \%$ on a range of Whole Foods products (Garfield 2017). It makes the probability to exercise the real option of the acquisition of Whole Foods very high. The acquisition-based dynamic capabilities helped Amazon to innovate a business model by getting managerial synergies as shown in Table 7. 
Table 7. The micro-foundations of the reconstructs of the business model of Amazon by acquisition-based dynamic capabilities.

\section{Acquisition Based Dynamic Capabilities of Amazon}

Identification, development, co-development, and assessment of technological opportunities concerning customer needs (sensing).
Micro-Foundations (Processes) of the Reconstruct of the Components of the Amazon Business Model

Amazon sensed that Whole Foods would provide broad access to retail outlets in a great location across the USA. Having exploited the big data strategy, Amazon can create a daily habit among buyers to order groceries from its app and to make them loyal clients who are highly profitable for the corporation.

Amazon seized a high-end brand name of Whole Foods and affluent buyers of Whole Foods. It also can reduce Amazon's supply chain management costs due to higher purchasing and bargaining power.

Having added grocery dynamic capabilities through the acquisition of Whole Foods, Amazon offers click-and-collect service for quality-conscious buyers, enjoys higher operating profit, and offers stores as points to pick up other online orders.
Continued renewal (transforming) customer relationships, new channels, and new customer value proposition.

Source: Developed by the author.

To measure dynamic capabilities-based synergies of Amazon acquisition, and to justify the proposition, the author used real options application employing BSOPM and BOPM. On 16 June 2017, the capitalization of Amazon was USD 478.6 bn; the capitalization of Whole Foods was USD 13.8 bn (Pillars of Wall Street 2017). The first valuation model used to measure dynamic capabilities-based synergies in M\&A deal was based on the Black-Scholes option pricing model (Black and Scholes 1973) as shown in Tables 8 and 9.

Table 8. Option variables to value dynamic capabilities-based synergies of Amazon and Whole Food's M\&A deal with BSOPM.

\begin{tabular}{|c|c|}
\hline Option Variables & Data \\
\hline $\mathrm{S}(\mathrm{o})$ & $\begin{array}{l}\text { The capitalization of Amazon was USD } 478.6 \mathrm{bn} \text {; the capitalization of Whole Foods was USD } 13.8 \mathrm{bn} \\
\text { (Pillars of Wall Street 2017). The cumulative capitalization of Amazon and Whole Foods is USD } \\
492.4 \mathrm{bn} \text {. }\end{array}$ \\
\hline $\mathrm{K}$ & $\begin{array}{l}\text { Having used Amazon revenues of USD } 142.6 \text { bn in } 2017 \text { and EV / Revenues multiple } 3.3 \text { (Pillars of } \\
\text { Wall Street 2017), the theoretical market value of Amazon without the acquisition of Whole Foods is } \\
\text { USD } 470.6 \text { bn. } \\
\text { Using Whole Foods EBITDA of } \$ 1.3 \text { bn in 2017, and EV / EBITDA multiple } 11.1 \text { (Pillars of Wall Street } \\
\text { 2017), the theoretical market value of Whole Foods without the deal is USD } 14.3 \text { bn. } \\
\text { Therefore, the cumulative theoretical market value of Amazon and Whole Foods without a deal or } \\
\text { the exercise price (K) equals USD } 484.9 \text { bn. }\end{array}$ \\
\hline Rf & The US Long-Term Government Bond T-bonds yield (10-years) in 2017 was 2.16\% (YCharts 2020). \\
\hline $\mathrm{T}$ & Time to expiration in years $(\mathrm{T})$ equals one year. \\
\hline$\sigma$ & $\begin{array}{l}\text { Expected volatility }(\sigma) \text { has been taken from AlphaQuery (2020). Following the AlphaQuery report } \\
\text { (AlphaQuery 2020), the volatility }(\sigma) \text { of Amazon after an announcement of the acquisition was } \\
\text { assumed as } 25.25 \% \text {. }\end{array}$ \\
\hline
\end{tabular}


Table 9. Valuation of dynamic capabilities-based synergies with the Black-Scholes option pricing model: Amazon's acquisition of Whole Food, in USD bn.

\section{Real Options Valuation with the Black-Scholes Option Pricing Model}

The cumulative market capitalization of Amazon and Whole Foods before the announcement (So) 492.40 Cumulative theoretical market value the separated entities without merger after one year $(\mathrm{K})$ The risk-free rate of return (Rf) in 2017 Time to expiration in years $(\mathrm{T})$

The volatility of future share price Amazon $(\sigma)$ in July of 2017, one week after the deal's announcement

Value of the call option $(\mathrm{C})=$ Synergies

Dynamic capabilities-based synergies of Amazon's acquisition of Whole Foods are USD 58.0 bn by BSOPM valuation. The valuation of the acquisition's synergies by the Binominal Option Pricing Model (BOPM) is USD 60.36 bn and is given in Tables 10-12.

Thus, the forecasted market capitalization of Amazon Inc. in one year after the acquisition is the cumulative capitalization of target and acquirer before the announcement(So) USD $492.40 \mathrm{bn}$ plus estimated synergies USD 59 bn, which equals USD $551.40 \mathrm{bn}$. Thereby, from an option-pricing point of view, this acquisition provides significant dynamic capabilities-based synergies. In short, Amazon's acquisition of Whole Foods was able to generate significant value-added for the acquirer's shareholders.

Table 10. Recombining binomial lattice parameters of Amazon's acquisition of Whole Foods.

\begin{tabular}{cc}
\hline \multicolumn{2}{c}{ The Binominal Option Pricing Model's Parameters } \\
\hline time increment (years) & $\delta \mathrm{t}=\frac{\mathrm{t}}{\mathrm{N}}=0.20$ \\
\hline up factor $(\mathrm{u})$ & $\mathrm{u}=\mathrm{e}^{\sigma / \Delta \mathrm{T}}=\frac{1}{\mathrm{~d}}=1.120$ \\
\hline down factor $(\mathrm{d})$ & $\frac{1}{\mathrm{u}}=0.893$ \\
\hline risk-neutral probability $(\mathrm{p})$ & $\mathrm{p}=\frac{\mathrm{e}^{\mathrm{r} \Delta \mathrm{T}}-\mathrm{d}}{\mathrm{u}-\mathrm{d}}=0.491$ \\
\hline
\end{tabular}

Table 11. BOPM lattice of the underline values of Amazon after the acquisition of Whole Foods (in USD bn).

\begin{tabular}{|c|c|c|c|c|c|}
\hline 0 & 1 & 2 & 3 & 4 & 5 \\
\hline \multirow[b]{5}{*}{$\begin{array}{l}\text { Underline } \\
\text { value }\end{array}$} & & & & & USD 866.01 \\
\hline & & & & USD 773.54 & \\
\hline & & & USD 690.94 & & USD 690.94 \\
\hline & & USD 617.16 & & USD 617.16 & \\
\hline & USD 551.26 & & USD 551.26 & & USD 551.26 \\
\hline \multirow[t]{5}{*}{ USD 492.40} & & USD 492.40 & & USD 492.40 & \\
\hline & USD 439.82 & & USD 439.82 & & USD 439.82 \\
\hline & & USD 392.86 & & USD 392.86 & \\
\hline & & & USD 350.91 & & USD 350.91 \\
\hline & & & & USD 313.44 & \\
\hline
\end{tabular}


Table 12. BOPM of real options lattice: a value of Amazon synergies of the acquisition of Whole Foods (in USD bn).

\begin{tabular}{|c|c|c|c|c|c|}
\hline 0 & 1 & 2 & 3 & 4 & 5 \\
\hline & & & & & USD 381.11 \\
\hline & & & & USD 290.73 & \\
\hline & & & USD 210.21 & & USD 206.04 \\
\hline & & USD 144.38 & & USD 134.35 & \\
\hline $\begin{array}{c}\text { Value of call } \\
\text { option } \\
\text { (synergies) }\end{array}$ & USD 94.99 & & USD 82.12 & & USD 66.36 \\
\hline \multirow[t]{4}{*}{ USD 60.36} & & USD 48.18 & & USD 32.44 & \\
\hline & USD 27.48 & & USD 15.86 & & USD 0.00 \\
\hline & & USD 7.75 & & USD 0.00 & \\
\hline & & & USD 0.00 & & USD 0.00 \\
\hline
\end{tabular}

Source: Developed by the author.

\section{Discussion and Contributions of Research}

Teece argues "that studies that provide a better understanding of business model innovation, implementation, and change will also shed light on important aspects of dynamic capabilities" (Teece 2018, p. 40). The paper contributes to this scientific discussion on the role of dynamic capabilities in business model innovation and justifies the proposition of Teece that "the crafting, refinement, implementation, and transformation of business models are outputs of high-order (dynamic) capabilities" (Teece 2018, p. 40).

Technological changes and new demand make previously acquired competencies obsolete and call for new competencies to be built (Danneels 2008, 2016). In this vein, empirical research is essential to the progress of research on dynamic capabilities (Danneels 2016) and on real options applications in strategic management (Trigeorgis and Reuer 2017). Jahanshahi and Nawaser (2018) argue that future research can test the relationship of a real options theory and dynamic capabilities framework in the project and firm-level (Jahanshahi and Nawaser 2018, p. 400). This paper contributes to this scientific discussion. The current paper justifies the role of dynamic capabilities as antecedents of success of M\&A deals and demonstrates real options application to measure managerial synergies in M\&A deals.

Moreover, the paper contributes and demonstrates how acquisition-based dynamic capabilities provide managerial synergies. Having tested empirically this relationship, the current paper enriches our knowledge about how organizations can benefit from real options and redefine dynamic capabilities framework to the heart of strategic management. This is the major theoretical contribution of the current paper.

Having explored two case studies, the proposition has been justified empirically. This paper contributes to the understanding of the micro-foundations of similarities and complementarity among dynamic capabilities of an acquirer and a target in M\&A deals in the ICT industry and the transferability of building blocks of their business models. Moreover, advancing future research designs for real options valuation, Trigeorgis and Reuer (2017, p. 57) argue "we would encourage the use of real option with a greater focus ... on individual real option cases". The current paper also contributes to the real options theory by two illustrative real option cases.

Thereby, the proposition has been justified quantitatively with an application of the Black-Sholes Option Pricing Model and Binominal Option Pricing Lattice techniques. To sum up theoretical and managerial contribution, the relationship among research variables is given in Figure 1. 


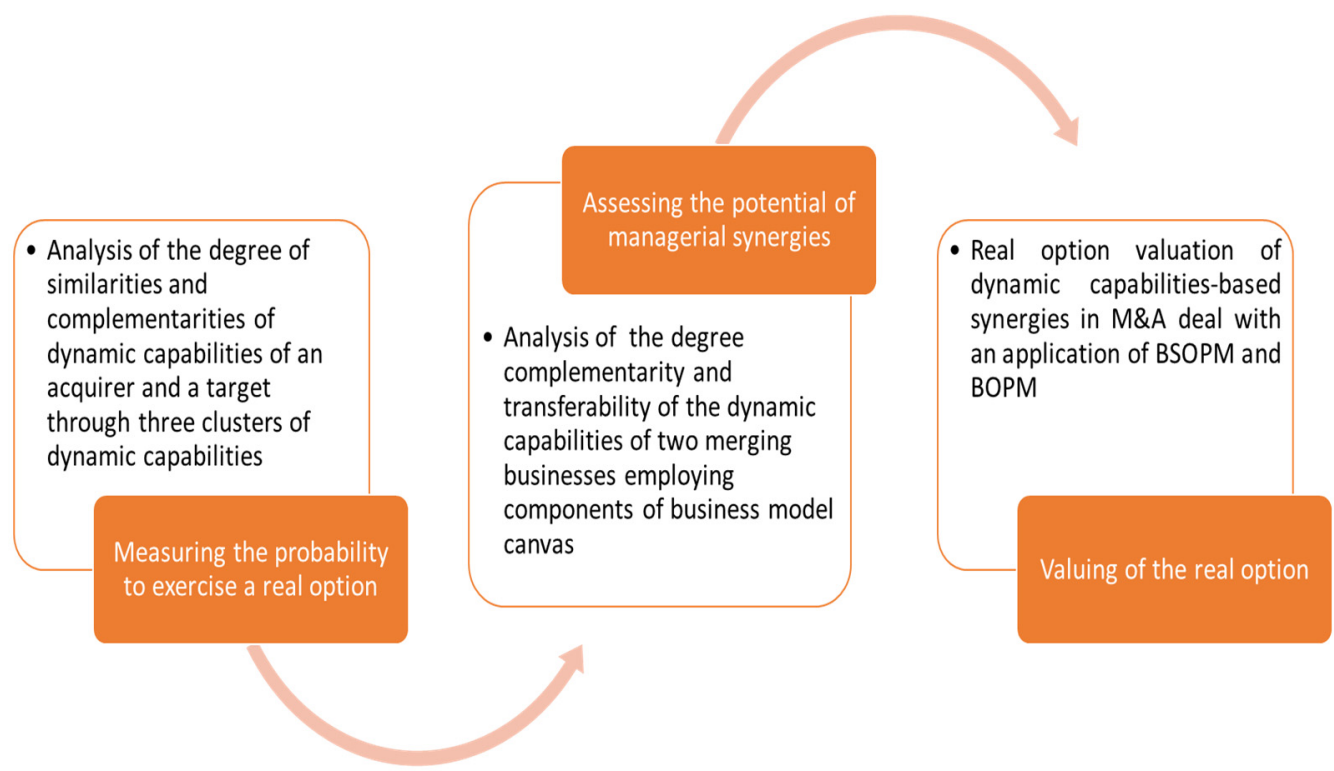

Figure 1. The relationship among research variables. Source: Developed by the author.

Figure 1 also presents the main proposed construct for future research as well as for practical due diligence purposes in the merging process. Acquirers need to absorb the dynamic capabilities of targets and to transfer building blocks of the target's business model on their own. Thereby, an acquirer converts an M\&A deal into a value creation process (synergies) that can be valued by real options.

\section{Conclusions, Limitations, and Future Research Direction}

Trigeorgis (1995) argued that it is crucially important that appropriate valuation techniques be employed to capture the various strategic considerations that could support many acquisitions. The paper contributes to this request as well. The relationship among research variables provides a dynamic view on M\&A deals to help executives in the sustaining of long-run competitive advantage and strategic adaptability.

Acquisition and alliance are some of the dynamic mechanisms by which the firm's competencies portfolio is altered (Danneels 2016). The acquisitions of Microsoft and Amazon of LinkedIn and Whole Foods were able to generate significant value-added for the acquirers' shareholders. "In most acquisitions, even those where synergy is real and creates value, the acquiring firm's stockholders get little or none of the benefits from synergy" (Damodaran 2005, p. 41), due to biased evaluation process and managerial hubris (pride). However, this statement is not about Microsoft and Amazon corporations.

The current paper also demonstrates the limitation of real options application to measure a dynamic capabilities-based synergy. It is difficult to validate the synergetic effect of one isolated acquisition deal when several acquisitions happen within the anticipation of the duration of achieving synergy. In this vein, more research is needed to justify the developed proposition.

Ongoing areas of an empirical investigation into dynamic capabilities, on topics such as acquisitions and alliances, among others, would also benefit from additional research (Schilke et al. 2018). What is more, exploration of dynamic capabilities to create new market-related and technological resources and their effects on managerial synergies (market value added) is an intriguing area for future research (Danneels 2016).

Funding: This research received no external funding.

Institutional Review Board Statement: Not applicable.

Informed Consent Statement: Not applicable. 
Conflicts of Interest: The authors declare no conflict of interest.

\section{References}

Adner, Ron, and Daniel Levinthal. 2004. What is Not a Real Option: Considering Boundaries to Application of Real Options to Business Strategy. Academy of Management Review 29: 74-84. [CrossRef]

AlphaQuery. 2020. Amazon.com, Inc. (AMZN). Available online: https:/ /www.alphaquery.com/stock/AMZN/volatility-optionstatistics/90-day/iv-mean (accessed on 28 January 2020).

Bauer, Florian, and Kurt Matzler. 2014. Antecedents on M\&A success: The role of strategic complementary, cultural fit, and degree and speed on integration. Strategic Management Journal 35: 269-91.

Black, Fisher, and Myron Scholes. 1973. The Pricing of Options and Corporate Liabilities. The Journal of Political Economy 81: 637-54. [CrossRef]

Capron, Laurence, and Jaideep Anand. 2007. Acquisition-based dynamic capability. In Dynamic Capabilities: Understanding Strategic Change in Organizations. Edited by C. E. Helfat, S. Finkelstein, W. Mitchell, M. Peteraf, H. Singh, D. Teece and S. Winter. London: Blackwell, pp. 80-99.

Clarence-Smith, Toby. 2020. Amazon vs. Walmart: Bezos Goes for the Jugular with Whole Foods Acquisition. Available online: https: //www.toptal.com/finance/mergers-and-acquisitions/amazon-vs-walmart-acquisition-strategy (accessed on 28 January 2020).

Corbo, Leonardo, Shadi Mahassel, and Alberto Ferraris. 2020. Translational Mechanisms in Business Model Design: Introducing the Continuous Validation Framework, Management Decision. Available online: https:/ /www.emerald.com/insight/0025-1747.htm (accessed on 25 September 2020).

Čirjevskis, Andrejs. 2017. Acquisition based dynamic capabilities and reinvention of a business model: Bridging two perspectives together. The International Journal Entrepreneurship and Sustainability 4: 516-25. [CrossRef]

Čirjevskis, Andrejs. 2019a. The Transformation of Business Models in Technology-Enabled M\&A: A Case Study of Amazon. Available online: https://www.researchgate.net/publication/332410397_The_Transformation_of_Business_Models_in_TechnologyEnabled_MA_A_Case_Study_of_Amazon (accessed on 17 September 2020).

Čirjevskis, Andrejs. 2019b. The Role of Dynamic Capabilities as Drivers of Business Model Innovation in Mergers and Acquisitions of Technology-Advanced Firms. Journal of Open Innovation: Technology, Market, and Complexity 5: 12. [CrossRef]

Damodaran, Aswath. 2002. Investment Valuation: Tools and Techniques for Determining the Value of Any Asset, 2nd ed. Hoboken: John Wiley \& Sons.

Damodaran, Aswath. 2005. The Value of Synergy, New York University—Stern School of Business. Available online: https://papers. ssrn.com/sol3/papers.cfm?abstract_id=841486 (accessed on 16 January 2020).

Danneels, Erwin. 2008. Organizational antecedents of second-order competences. Strategic Management Journal 29: 519-43. [CrossRef]

Danneels, Erwin. 2016. Survey measures of first- and second-order competencies. Strategic Management Journal 37: 2174-88. [CrossRef]

Dunis, Chrisitian, and Til Klein. 2005. Analyzing Mergers and Acquisitions in European Financial Services: An Application of Real Options. European Journal of Finance 11: 339-55. [CrossRef]

Eisenhardt, Kathleen M., and Jeffrey A. Martin. 2000. Dynamic capabilities: What are they? Strategic Management Journal 21: 1105-21. [CrossRef]

Easterby-Smith, Mark M., and Isabel M. Prieto. 2008. Dynamic Capabilities and Knowledge Management: An Integrative Role for Learning? British Journal of Management 19: 235-49. [CrossRef]

Ficery, Kristin, Tom Herd, and Bill Pursche. 2007. Strategy in Action. Accenture. Available online: http://www.firstcalladvisors.com/ files/TheSynergyEnigma_4.pdf (accessed on 28 January 2020).

Garfield, Leanna. 2017. Whole Foods CEO: Amazon Saved Us from the 'Whole Paycheck' Trap. Available online: https://www. businessinsider.com/whole-foods-ceo-amazon-reputation-lower-prices-2017-9 (accessed on 19 August 2019).

Helmore, Edward. 2017. Hard Times for Whole Foods: People Say It's for Pretentious People. I Can See Why. The Guardian. Available online: https:/ / www.theguardian.com/business/2017/apr/29/whole-foods-hard-times-retail (accessed on 19 August 2020).

Jahanshahi, Asghar Afshar A., and Khaled Nawaser. 2018. Are real options reasoning a cause or consequence of dynamic capability? Strategic Change 27: 395-402. [CrossRef]

Kleinbaum, Adam M., and Toby E. Stuart. 2014. Inside the black box of the corporate staff: Social networks and the implementation of corporate strategy. Strategic Management Journal 35: 24-47. [CrossRef]

Kogut, Bruce. 1991. Joint Ventures and the Option to Expand and Acquire. Management Science 37: 19-33. [CrossRef]

Kowitt, Bruce. 2018. How Amazon Is Using Whole Foods in a Bid for Total Retail Domination. Available online: https://fortune.com/ longform/amazon-groceries-fortune-500/ (accessed on 19 August 2020).

Li, Yong, Barclay E. James, Ravi Madhavan, and Joseph T. Mahoney. 2007. Real Options: Taking Stock and Looking Ahead. Advances in Strategic Management 24: 31-66.

Luehrman, Timothy A. 1998. Investment Opportunities as Real Options: Getting Started on the Numbers. Harvard Business Review. Available online: http:/ / pages.stern.nyu.edu/ adamodar/pdfiles/articles/InvestmentsasOptions.pdf (accessed on 2 February 2021).

Macrotrends. 2020. 10 Year Treasury Rate. Available online: https:/ /www.macrotrends.net/2016/10-year-treasury-bond-rate-yieldchart (accessed on 17 September 2020). 
Microsoft. 2016. Leadership. Microsoft and LinkedIn Conference Call: Chris Suh, Satya Nadella, Jeff Weiner, Amy Hood, Brad Smith. Available online: https://news.microsoft.com/speeches/microsoft-and-linkedin-conference-call-chris-suh-satya-nadella-jeffweiner-amy-hood-brad-smith / (accessed on 17 September 2020).

Microsoft Corp GARCH Volatility Analysis. 2020. Available online: https://vlab.stern.nyu.edu/analysis/VOL.MSFT:US-R.GARCH (accessed on 17 September 2020).

Nishihara, Michi. 2012. Real options with synergies: Static versus dynamic policies. Journal of the Operational Research Society 63: 107-21. [CrossRef]

Nishihara, Mochi. 2018. Valuation of an RandD project with three types of uncertainty. EURO Journal on Decision Processes 6: 93-113. [CrossRef]

Pillars of Wall Street. 2017. Deal of the Week: Amazon to Buy Whole Foods for \$13.4B. Available online: https: / pillarsofwallstreet. com/wp-content/uploads/2013/02/6.16.17-Amazon-to-Buy-Whole-Foods-for-13.4B.pdf (accessed on 28 January 2020).

Pillars of Wall Street. 2020. Deal of the Week: Microsoft to Buy LinkedIn for 26.2 bn. Available online: https:/ / pillarsofwallstreet.com/ wp-content/uploads/2013/02/6.13.16-Microsoft-to-Buy-LinkedIn-for-26.2B.pdf (accessed on 17 September 2020).

Ragozzino, Roberto, Jeffrey J. Reuer, and Lenos Trigeorgis. 2016. Real options in strategy and finance: Current gaps and future linkages. Academy of Management Perspectives 30: 428-40. [CrossRef]

Sapersen, Jeff, and Mariela Gonzales. 2017. LinkedIn Bridging the Global Employment Gap. London: Ivey Publishing, pp. 1-9.

Schilke, Oliver, Songcui Hu, and Constance E. Helfat. 2018. Quo vadis, dynamic capabilities? A content-analytic review of the current state of knowledge and recommendation for future research. Academy of Management Annals 12: 390-439. [CrossRef]

Signoria, Andrea, and Silvio Vismara. 2018. M\&A synergies and trends in IPOs. Technological Forecasting and Social Change 127: 141-53.

Smith, Kenneth W., and Alexander J. Triantis. 1995. The Value of Options in Strategic Acquisitions. In Real Options Capital Investment: Models, Strategies and Applications. Edited by Lenos Trigeorgis. London: Praeger.

Smit, Han T. J., and Lenos Trigeorgis. 2004. Strategic Investment: Real Options and Games. Princeton NJ: Princeton University Press, p. 505.

Teece, David J., Gary Pisano, and Amy Shuen. 1997. Dynamic Capabilities, and Strategic Management. Strategic Management Journal 18: 509-33. [CrossRef]

Teece, David J. 2007. Explicating dynamic capabilities: The nature and micro-foundations of (sustainable) enterprise performance. Strategic Management Journal 28: 1319-50. [CrossRef]

Teece, David J. 2010. Business Models, Business Strategy, and Innovation. Long Range Planning 43: 172-94. [CrossRef]

Teece, David J. 2011. Dynamic Capabilities: A Guide for Managers. Available online: http:/ /iveybusinessjournal.com/publication/ dynamic-capabilities-a-guide-for-managers / (accessed on 29 December 2018).

Teece, David J. 2014. The foundations of enterprise performance: Dynamic and ordinary capabilities in an (economic) theory of firms. Academy of Management Perspective 28: 328-52. [CrossRef]

Teece, David J. 2018. Business models and dynamic capabilities. Long Range Planning 51: 40-49. [CrossRef]

Trigeorgis, Lenos, ed. 1995. Real Options in Capital Investment: Models, Strategies, and Applications. Westport: Praeger Publisher.

Trigeorgis, Lenos, and Jeffrey J. Reuer. 2017. Real options theory in strategic management. Strategic Management Journal 38: 42-63. [CrossRef]

Vergos, Konstantinos. 2003. Real Options and the Pricing of Shares. Ph.D. dissertation, University of Wales, Bangor, UK.

Wilden, Ralf, Timothy M. Devinney, and Grahame R. Dowling. 2016. The Architecture of Dynamic Capability Research: Identifying the Building Blocks of a Configurational Approach. Academy of Management Annals 10: 997-1076. [CrossRef]

Winter, Sidney G. 2003. Understanding dynamic capabilities. Strategic Management Journal 24: 991-95. [CrossRef]

YCharts. 2020. 10 Year Treasury Rate. Available online: https://ycharts.com/indicators/10_year_treasury_rate (accessed on 27 January 2020).

Zollo, Maurizio, and Sydney G. Winter. 2002. Deliberate Learning and the Evolution of Dynamic Capabilities. Organization Science 13: 339-51. [CrossRef] 